\title{
Article \\ Regulating Vapor Pressure Deficit and Soil Moisture Improves Tomato and Cucumber Plant Growth and Water Productivity in the Greenhouse
}

\author{
Xiaoming Song, Lili Miao, Xiaocong Jiao, Musawar Ibrahim and Jianming Li * \\ College of Horticulture, Northwest Agriculture \& Forest University, Yangling 712100, China; \\ songxiaoming1992@163.com (X.S.); miaolilis@163.com (L.M.); xiaocongjiao1991@163.com (X.J.); \\ musawaribrahim3@gmail.com (M.I.) \\ * Correspondence: lijianming66@163.com; Tel.: +86-029-87082452
}

Citation: Song, X.; Miao, L.; Jiao, X.; Ibrahim, M.; Li, J. Regulating Vapor Pressure Deficit and Soil Moisture Improves Tomato and Cucumber Plant Growth and Water Productivity in the Greenhouse. Horticulturae 2022, 8, 147. https://doi.org/10.3390/ horticulturae 8020147

Academic Editor: Pietro Santamaria

Received: 13 December 2021

Accepted: 6 February 2022

Published: 9 February 2022

Publisher's Note: MDPI stays neutral with regard to jurisdictional claims in published maps and institutional affiliations.

Copyright: (C) 2022 by the authors. Licensee MDPI, Basel, Switzerland. This article is an open access article distributed under the terms and conditions of the Creative Commons Attribution (CC BY) license (https:// creativecommons.org/licenses/by/ $4.0 /)$

\begin{abstract}
Atmospheric vapor pressure deficit (VPD) is the driving force that regulates the rate of water transport within plants. Under High VPD (HVPD), plants always reduce their photosynthesis rate and close their stomata. Experiments were performed under greenhouse conditions with cucumber and tomato plants to identify the regulatory effect of VPD on plant water capacity. Treatments included two levels of soil water $(100 \%$ and $60 \%$ field capacity [FC]) combined with two levels of VPD (LVPD and HVPD). Results indicated that with $60 \% \mathrm{FC}$, the plant heights of tomato and cucumber were enhanced under LVPD compared with those under HVPD. With $60 \%$ FC, relative leaf water contents under LVPD increased by $11 \%$ compared with those under HVPD. Furthermore, LVPD significantly improved the photosynthetic capacity of the two crops and changed their stress responses. Our results indicated that LVPD at different soil moisture levels reduced irrigation demand under greenhouse conditions. This approach can be applied in water management in greenhouse vegetable production in China and other regions of the world with temperate continental climates.
\end{abstract}

Keywords: vapor pressure deficit; soil water; drought stress; tomato; cucumber

\section{Introduction}

Water is one of the indispensable regulating factors of plant growth and development, given that it affects most of the physiological and biophysical properties of plants [1]. Vapor pressure deficit (VPD) is the difference between air saturation vapor pressure and actual air vapor pressure based on air relative humidity and temperature [2]. It can be used to determine atmospheric water status in a controlled environment [3]. In greenhouses, the high evapotranspiration from plants and soils caused by high VPD (HVPD) leads to reductions in soil moisture content [4]. Natural fogging is performed to increase air humidity, which reduces plant evapotranspiration rates [5]. Additional fogging not only decreases evapotranspiration but also enhances plant growth [6]. Previous studies have shown that differences in the levels of air humidity and VPD have effects on the growth and functions of different horticultural crops [7]. Thus, the responses of plants to dehydration, soil moisture, and VPD can be used as basic parameters to determine plant water status.

Low water availability is one of the most important manifestations of abiotic stress in plants [8]. It is the major yield-limiting issue for crops, and it strongly and continuously regulates natural circulation in plant species [9]. The high transpiration rate (Tr) under HVPD causes water deficiency in plants [10]. The decrement in leaf water content and photosynthetic rate finally affects plant growth [11].

Stomata are a key constituent of plant leaves with an important role in gaseous exchange [12]. Abscisic acid (ABA) plays an important role in stomatal behavior [13]. The rapid accumulation of ABA when the plant senses drought causes stomatal closure [14]. Long-term HVPD and water stress (WS) also negatively influence stomatal morphology [15]. 
Plants subjected to low VPD (LVPD) exhibit large stomatal apertures [16], whereas those under WS conditions have relatively small stomata [17]. However, the responses of stomata and photosynthesis to LVPD in soil under water-scarce conditions still need to be investigated. Furthermore, previous studies did not clearly discuss the maintenance of balance by plants under such conditions.

Water deficit can cause changes in plant internal metabolism [9]. Long-term water deficiency may result in oxidative damage due to the overproduction of reactive oxygen species (ROS) [18]. ROS affect almost every aspect of plant homeostasis and negatively regulate growth and development [19]. Under WS conditions, plant roots sense the low water potential in the soil and activate several stress-related signal transduction pathways that alter the levels of plant carbon dioxide and cellular oxygen [20]. This effect may further lead to the partial closure of stomata in the leaves and retard plant growth. Plants are equipped with defense mechanisms to alleviate stress effects [21]. These systems consist of enzymatic and nonenzymatic antioxidants, which scavenge ROS that are overproduced under stress conditions [22]. The enzymatic antioxidants superoxide dismutase (SOD), peroxidase (POD), and catalase (CAT) have a key role in stress tolerance $[23,24]$.

Tomato (Solanum lycopersicum L.) and cucumber (Cucumis sativus L.) are the most economically important vegetables that are grown worldwide. Several studies have elucidated the effects of air humidity and soil moisture on the physiology of cucumber and tomato plants but did not elaborate on their interactive effects. In this study, we systemically investigated plant growth and photosynthesis and examined leaf antioxidant enzyme systems in a controlled environment. This study will advance the understanding of the responses of vegetables to soil moisture and atmospheric humidity. It could be useful in future crop improvement programs.

\section{Materials and Methods}

\subsection{Experimental Design}

The effects of the prepared treatment combinations were examined in two independent experiments by using tomato (cv. "Jinpeng8b") and cucumber (cv. "Bonai3000") plants grown during spring and fall in the greenhouses of the Northwest Agriculture and Forestry University $\left(34^{\circ} 150^{\prime} \mathrm{N}, 108^{\circ} 04^{\prime} \mathrm{E}\right)$, China. Tomato plants were grown from 7 February 2018 to 8 May 2018. Cucumber plants were grown in the same greenhouse from 15 September 2018 to 8 November 2018. Both greenhouses were $10 \mathrm{~m}$ in length, $5 \mathrm{~m}$ in width, and $3 \mathrm{~m}$ in height. Seeds were sown in controlled-environment chambers (RDN1000D-4, Southeast Instrument Co., Ltd., Ningbo, China) for germination $\left(22{ }^{\circ} \mathrm{C} / 18{ }^{\circ} \mathrm{C}\right.$ for day/night temperature; white fluorescent lamps with $600 \mu \mathrm{mol} \mathrm{m}^{-2} \mathrm{~s}^{-1}$ PAR). After 4 weeks, plant seedlings at the five-true-leaf stage were transplanted into plastic pots (capacity: $4.82 \mathrm{~L}, 19 \mathrm{~cm} \times 17 \mathrm{~cm}$, diameter $\times$ depth). Each pot contained one plant and $8 \mathrm{~kg}$ of horticultural organic substrate (customized mixes, PINDSTRUP Co., Ryomgaard, Denmark), which can provide sufficient nutrition throughout the whole duration of the experiment. The organic substrate had a density of $0.366 \mathrm{~g} \mathrm{~cm}^{-3}$ and $\mathrm{pH}$ of 6.93 . The available N, P, K, and organic matter contents were 2343.51, 1026.66, 2312.01, and $210.54 \mathrm{~g} \mathrm{~kg}^{-1}$, respectively. In accordance with the instructions included with the substrate, the relative field water capacity (FC) of the tomato cultivation substrate was maintained at not less than $75 \%$.

\subsection{Plant Materials}

Tomato seeds were obtained from Xian Jinpeng Seedlings Company, Ltd., Xi'an, China, Cucumber seeds were procured from Tianjin Derit Seeds Company, Ltd., Tianjin, China. The seeds were sown in a plastic tray and watered properly to obtain seedlings.

\subsection{Treatment Combination}

Two levels of FC (100\% and 60\%FC) and two levels of VPD (HVPD and LVPD) were used in the combinations shown in Table 1. 
Table 1. Experimental treatments.

\begin{tabular}{ccc}
\hline & HVPD & LVPD \\
\hline Well-watered soil & $100 \% \mathrm{FC}+$ HVPD & $100 \% \mathrm{FC}+\mathrm{LVPD}$ \\
Water-stress soil & $60 \% \mathrm{FC}+\mathrm{HVPD}$ & $60 \% \mathrm{FC}+\mathrm{LVPD}$ \\
\hline
\end{tabular}

FC: Soil relative water capacity. HVPD: 3-6 KPa; LVPD: 1.5-2.5 KPa.

The treatments were started by withholding water until the compost moisture of the drought stress treatments reached $60 \% \mathrm{FC}$. Meanwhile, the soil moisture was well maintained for the $100 \% \mathrm{FC}$ treatment. The VPD control method was based on the greenhouse VPD control system designed by our research group [25]. Briefly, LVPD was maintained at below $1.5 \mathrm{KPa}$ by increasing air humidity with a fogging system (machine output air moisture diameter: 5-10 $\mu \mathrm{m}$, water vapor output per hours: 1-3 L, MCH-03, Gemei Electric Co., Ltd., Suzhou, China). For HVPD, the greenhouse air humidity was unregulated (Figure S1). In the spring tomato experiment, HVPD reached the maximum of $6 \mathrm{KPa}$ (Figure 1A), and in the autumn cucumber experiment, it reached the maximum of $4.5 \mathrm{KPa}$ (Figure 1B).

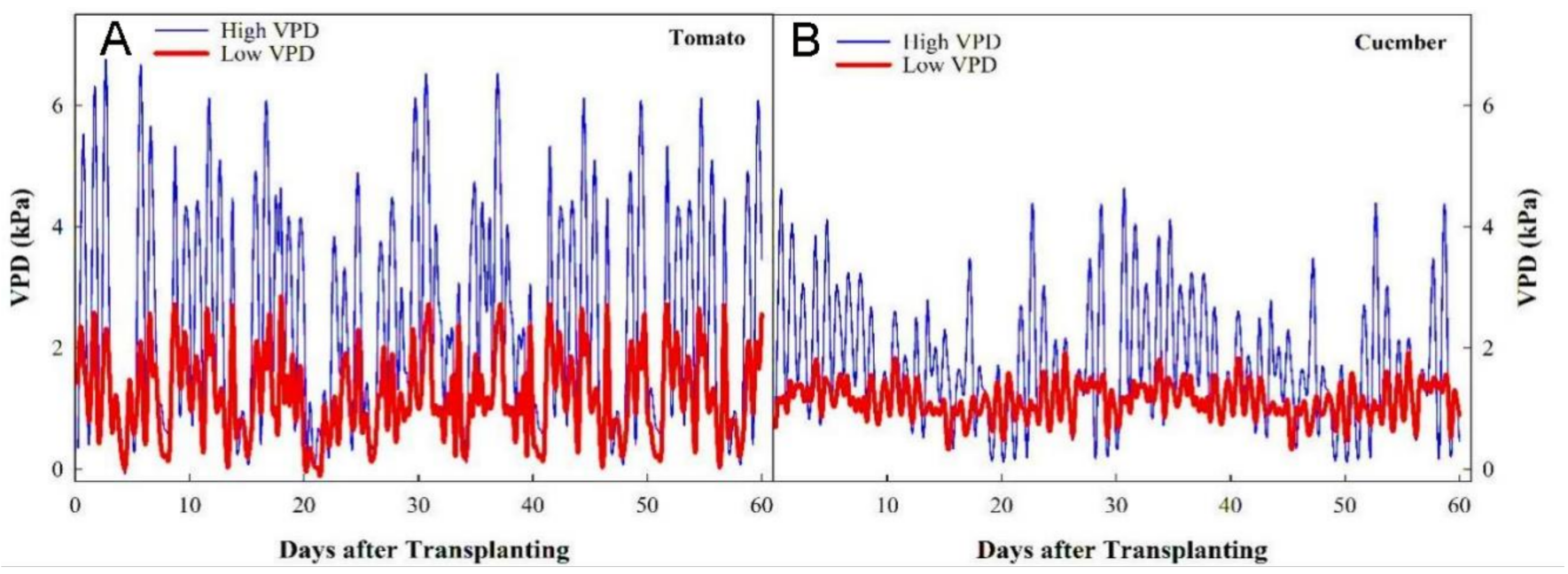

Figure 1. Experimental greenhouse environmental parameters. (A): Tomato plants were grown from 7 February 2018 to 8 May 2018. (B): Cucumber plants were grown in the same greenhouse from 15 September 2018 to 8 November 2018.

For all plants, aluminum foil was used to cover the surface of the soil. The aluminum foil was closely integrated with the edge of the pot and the plants to prevent the evaporation of water from the soil surface. The pots were weighed and watered every afternoon to maintain the FC level. Physiological data were measured every 10 days after planting in the tomato experiment and every 15 days in the cucumber experiment. A total of 150 plants were cultivated for each treatment, and Fan equipment was installed above the center of the greenhouse to facilitate air circulation. At the same time, a comprehensive plant protection policy was strictly implemented during the experiment to maintain the cleanliness of the greenhouse and avoid the occurrence of plant diseases under high air humidity.

\subsection{Plant Morphological Parameters}

Ten plants with equal growth were selected per treatment for the measurement of plant height, stem diameter, and plant fresh and dry biomasses. Plant height (in $\mathrm{cm}$ ) was recorded by using a measuring tape. Data on stem diameter (in $\mathrm{mm}$ ) were collected from three different positions on the plant (i.e., bottom, middle, and top) by using Vernier calipers, and the averages of these data were used to represent the stem diameter of the plant [11]. For plant biomass, shoot fresh weight and root fresh weight (in g) were measured by weighing with a weight balance. Afterwards, the plant material was kept in the oven for $72 \mathrm{~h}$ at $65^{\circ} \mathrm{C}$ for the determination of plant dry biomass [11]. 


\subsection{Photosynthetic Parameters}

The net photosynthesis rate (Pn), intercellular carbon dioxide concentration $(\mathrm{Ci})$, stomatal conductance (Gs), and transpiration rate ( $\mathrm{Tr}$ ) of the tomato and cucumber seedlings were measured in the spring and fall at three different time points with 15-day intervals (9:00 a.m. to 11:00 a.m.) by using a portable system (Li-6800, Li-Cor, Inc., Lincoln, NE, USA). All measurements were carried out at the $\mathrm{CO}_{2}$ concentration of $400 \mu \mathrm{mol} \mathrm{mol}^{-1}$, photosynthetic photon flux density of $1000 \mu \mathrm{mol} \mathrm{m}{ }^{-2} \mathrm{~s}^{-1}$, and leaf temperature of $30^{\circ} \mathrm{C}$. The VPD was set at 1.5 KPa for LVPD and 3.0 KPa for HVPD.

\subsection{Relative Water Content}

Fresh leaves were selected to examine the relative water content (RWC) through the gravimetric method [7]. Briefly, the selected fresh leaves were weighed immediately by using an electronic balance (type: JA5003; weighing range: 0-500 g; accuracy value: 0.001 g; Lichen Technology Co., Shaoxing, China) and kept in distilled water in the dark until they reached a constant weight (full turgor after $24 \mathrm{~h}$ ). Later, the leaves were dried at $60{ }^{\circ} \mathrm{C}-80{ }^{\circ} \mathrm{C}$ to obtain the dry weight. Finally, the RWC was calculated by using the following Formula (1) described by Dalong Zhang [26]:

RWC $(\%)=($ fresh weight - dry weight $) /($ saturated weight - dry weight $) \times 100$

\subsection{Leaf Electrolyte Leakage}

For the determination of leaf electrolyte leakage (EC), small pieces were cut from the plant's newly fully expanded leaves, from the top of the plant, and placed in distilled water at $25^{\circ} \mathrm{C}$ for $3 \mathrm{~h}$. Subsequently, the leaf water solution was measured by using an EC meter (DDS-307A, Leici Technology Co., Shanghai, China). This initial measurement was represented as $\mathrm{L}_{\mathrm{t}}$. Afterwards, the same leaf samples were placed in a hot water bath (HH-4, Lichen Technology Co., Shanghai, China) at $100{ }^{\circ} \mathrm{C}$ for $15 \mathrm{~min}$ and then used for the second reading of $\mathrm{L}_{\mathrm{O}}$. EC was calculated by using the following Formula (2) described by Huan Liu [27]:

$$
\mathrm{EC}=\left(\mathrm{L}_{\mathrm{t}} / \mathrm{L}_{\mathrm{o}}\right) \times 100
$$

\subsection{Chlorophyll Content}

Leaf chlorophyll contents were determined by using $0.15 \mathrm{~g}$ of fresh leaf sample extracted in $95 \%$ ethanol solution. The extract was placed at $25{ }^{\circ} \mathrm{C}$ for $24 \mathrm{~h}$ in the dark. Subsequently, the absorbance of the extract was measured by using a spectrophotometer (UV-3802, UNICO Instrument Co., Dayton, NJ, USA) to observe the chlorophyll a $\left(\mathrm{C}_{\mathrm{a}}\right)$, and chlorophyll $b\left(C_{b}\right)$, contents at the wavelengths of $A_{665}$ and $A_{649} n m$, respectively. Chlorophyll concentrations were calculated by using the Equations (3) and (4) described by Liu Guoying [28]:

$$
\begin{aligned}
& \mathrm{C}_{\mathrm{a}}=13.95 \mathrm{~A}_{665}-6.88 \mathrm{~A}_{649} \\
& \mathrm{C}_{\mathrm{b}}=24.96 \mathrm{~A}_{649}-7.32 \mathrm{~A}_{665} .
\end{aligned}
$$

\subsection{Antioxidant Enzymes}

A total of $0.2 \mathrm{~g}$ of fresh leaf sample was ground in liquid nitrogen, then centrifuged at $12,000 \times g$ in phosphate buffer $(\mathrm{pH} 7.8)$ at $4{ }^{\circ} \mathrm{C}$ for $20 \mathrm{~min}$. The obtained supernatant was used to analyze superoxide dismutase (SOD), peroxidase (POD), catalase (CAT), and ascorbate peroxidase (APX) activities and malondialdehyde (MDA) content.

For the measurement of SOD activities, one unit of SOD activity was defined as the amount of enzyme needed for 50\% inhibition of the decrease in nitro blue tetrazolium (NBT), as monitored at $560 \mathrm{~nm}$ (UV-3802, UNICO Instrument Co., Dayton, NJ, USA) [29]. POD activity was determined through the guaiacol [30]. Absorbance was observed at $470 \mathrm{~nm}$ for $3 \mathrm{~min}$ with $30 \mathrm{~s}$ intervals by using a Multiple-label Multifunctional Microplate Reader (SpectraMax i3x, Molecular Devices, LLC. San Jose, CA, USA). CAT activity was measured by monitoring the decreases in $\mathrm{H}_{2} \mathrm{O}_{2}$ at $240 \mathrm{~nm}$ for $2 \mathrm{~min}$ [31]. APX activity was 
assayed by monitoring the decreases of ascorbate at $290 \mathrm{~nm}$ for $2 \mathrm{~min}$ [31]. MDA content was measured using the thiobarbituric acid test at three different wavelengths $(450,532$, and $600 \mathrm{~nm})$ [32].

\subsection{Statistical Analysis}

The obtained data were subjected to two-way analysis of variance with a factorial arrangement. The analyzed results were subjected to least significant difference analysis $(p<0.05)$. Statistix V.8.1 and Microsoft Excel were used for statistical analysis. Graphs were prepared by using Sigma-Plot version 12.5 software. The $p$-value and correlation coefficients of all experimental parameters are provided in the appendix in the Supplementary Material (Table S1; Figure S2).

\section{Results}

\subsection{Effects of VPD and Soil Moisture on RWC and EC}

With the passage of time, a small increase in RWC (0-30 days) was observed in tomato plants but not in cucumber plants. RWC was lower under HVPD with $100 \%$ and $60 \%$ FC compared with LVPD with $100 \%$ and $60 \%$ in tomato plants. In cucumber plants, the RWC was highest under 100\%FC and LVPD after 45 days, when it reached $90.02 \%$ (Figure 2).

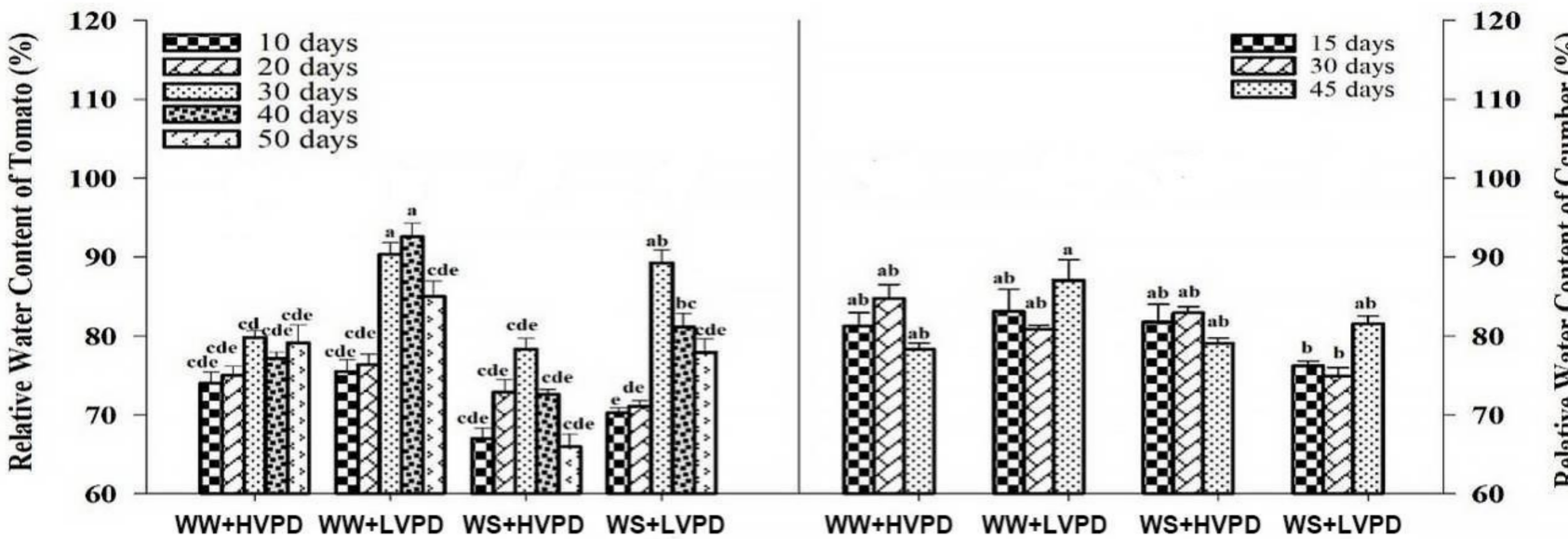

Figure 2. Effects of VPD and soil moisture on the RWC of tomato and cucumber plants. Data represent means \pm standard error $(n=10)$. Letters represent significant differences between treatments. Different letters indicate significant differences $(p<0.05)$. WW (well-watered, $100 \% \mathrm{FC})+$ HVPD (high vapor pressure deficit); WW (well-watered, 100\%FC) + LVPD (low vapor pressure deficit); WS (water stress, 60\%FC) + HVPD (high vapor pressure deficit); WS (water stress, 60\%FC) + LVPD (low vapor pressure deficit).

The EC in tomato plants was negligibly different from that in cucumber plants. The EC in tomato plants increased synchronously with the plant growth time, but the EC was highest with $60 \% \mathrm{FC}$ with LVPD after 20 days. In cucumber plants, the EC was highest with $100 \%$ FC with LVPD after 15 days. The EC in cucumber plants decreased gradually as the experiment continued, which was a different pattern with tomato (Figure 3).

\subsection{Effects of VPD and Soil Moisture on Photosynthetic Parameters}

The gas exchange parameters Ci, Gs, Pn, and Tr in tomato (Figure 4) and cucumber (Figure 5) plants were measured at 15-day intervals. In tomato plants, $\mathrm{Ci}$ was higher under HVPD with $100 \%$ FC after 15 days. Gs and Pn showed the same trend, which increased to the maximum under LVPD with 100\%FC. Tr was highest under LVPD with 100\% and $60 \%$ FC than the other two treatments on different days. In cucumber plants, the maximum $\mathrm{Ci}$ was observed under LVPD with $60 \%$ FC after 30 days, which was much higher than $\mathrm{Ci}$ under LVPD with $100 \%$ FC after 30 days. Gs increased under LVPD conditions on different days. The trend of Pn was similar to that of Gs, and Pn was higher under LVPD with 
$60 \%$ FC after 30 days. Tr was higher under LVPD with $100 \%$ and $60 \%$ FC than the other two treatments.

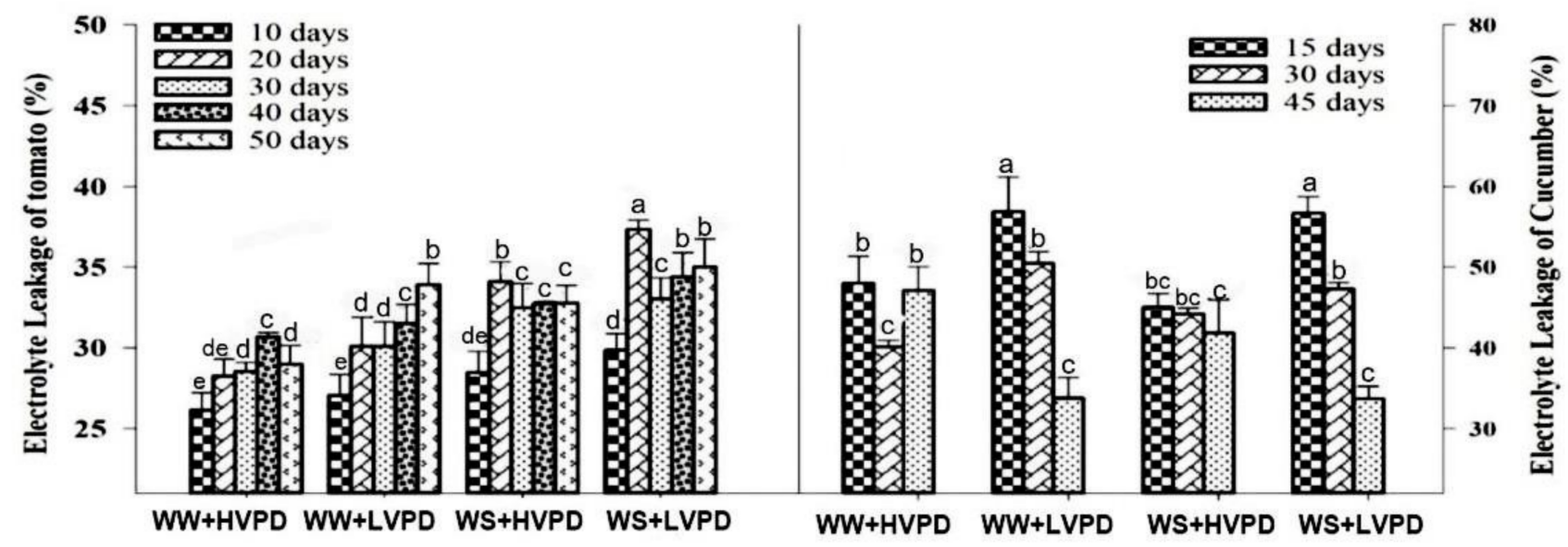

Figure 3. Effects of VPD and soil moisture on the EC of tomato and cucumber plants. Data are presented as means \pm standard error $(n=10)$. Letters represent significant differences between treatments. Different letters indicate significant difference $(p<0.05)$. WW (well-watered, 100\%FC) + HVPD (high vapor pressure deficit); WW (well-watered, 100\%FC) + LVPD (low vapor pressure deficit); WS (water stress, 60\%FC) + HVPD (high vapor pressure deficit); WS (water stress, 60\%FC) + LVPD (low vapor pressure deficit).
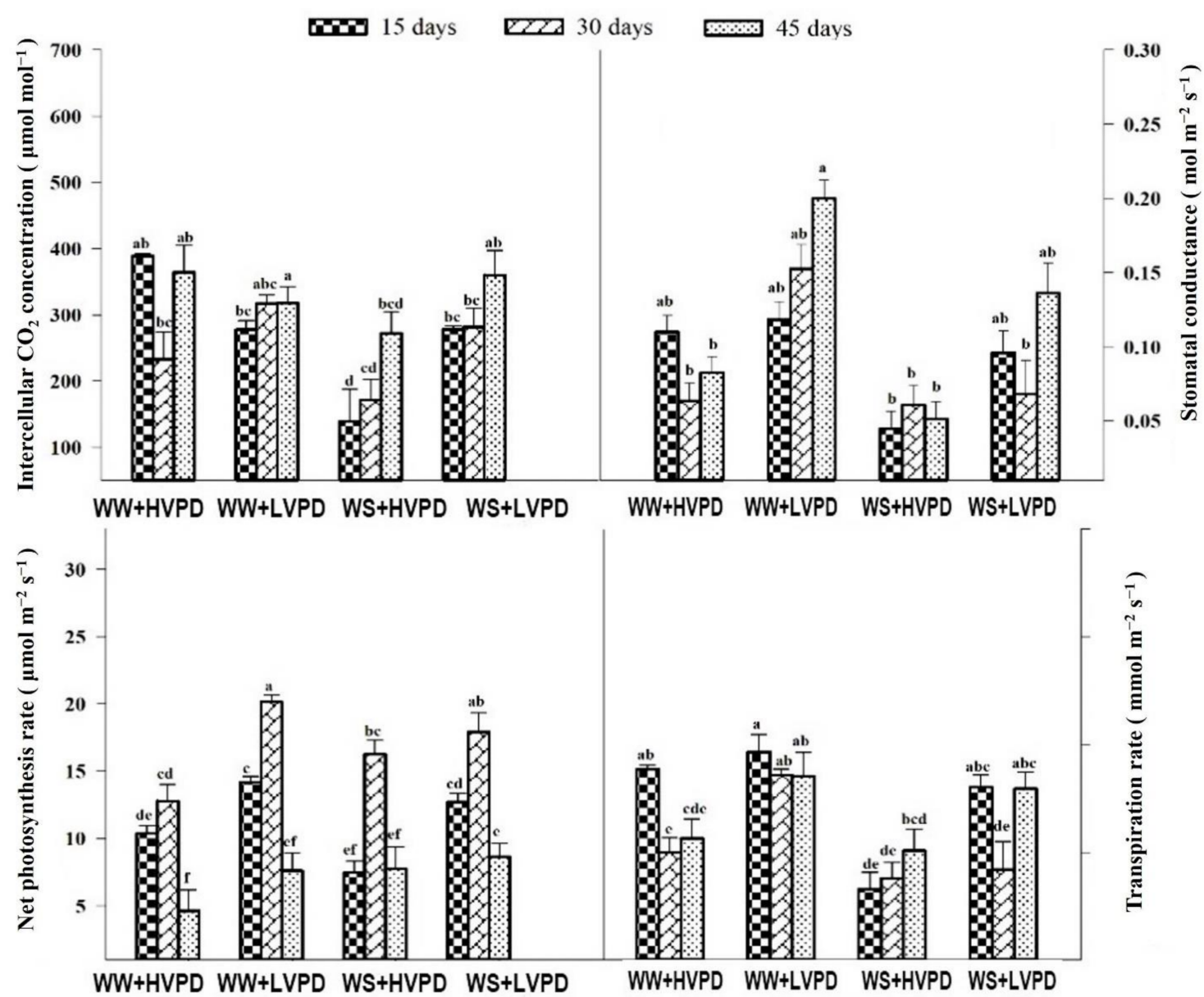

Figure 4. Effects of VPD and soil moisture on the net photosynthesis rate (Pn), intercellular carbon dioxide concentration $(\mathrm{Ci})$, stomatal conductance $(\mathrm{Gs})$, and transpiration rate (Tr) of tomato plants. 
Data are presented as mean \pm standard error $(n=10)$. Letters represent significant differences between treatments. Different letters indicate significant difference $(p<0.05)$. WW (well-watered, $100 \%$ FC) + HVPD (high vapor pressure deficit); WW (well-watered, 100\%FC) + LVPD (low vapor pressure deficit); WS (water stress, $60 \% \mathrm{FC}$ ) + HVPD (high vapor pressure deficit); WS (water stress, $60 \% \mathrm{FC}$ ) + LVPD (low vapor pressure deficit).

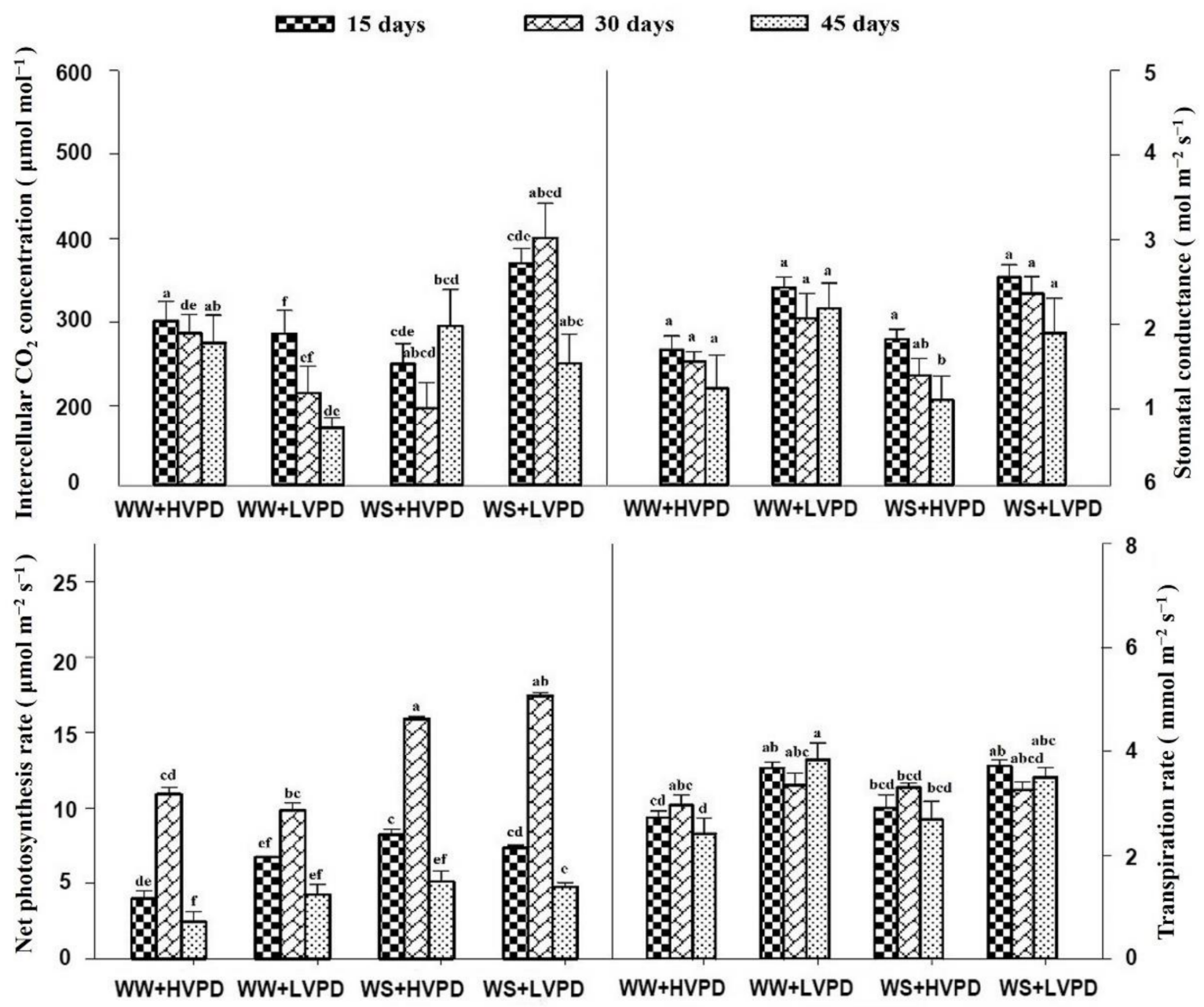

Figure 5. Effects of VPD and soil moisture on the net photosynthesis rate (Pn), intercellular carbon dioxide concentration (Ci), stomatal conductance (Gs), and transpiration rate (Tr) of cucumber plants. Data represent means \pm standard error $(n=10)$. Letters represent significant differences between treatments. Different letters indicate significant differences $(p<0.05)$. WW (well-watered. $100 \%$ FC) + HVPD (high vapor pressure deficit); WW (well-watered, 100\%FC) + LVPD (low vapor pressure deficit); WS (water stress, 60\%FC) + HVPD (high vapor pressure deficit); WS (water stress, $60 \% \mathrm{FC}$ ) + LVPD (low vapor pressure deficit).

\subsection{Effects of VPD and Soil Moisture on Plant Height and Diameter}

Our results showed that VPD altered the plant heights and stem diameters of tomato and cucumber plants (Table 2). Plant heights with $100 \%$ FC were significantly higher than with $60 \% \mathrm{FC}$ in tomato plants. Their stem diameter reached the maximum with $100 \%$ FC + LVPD conditions. The plant height and stem diameter of cucumber plants with $100 \%$ FC + LVPD treatment were also significantly higher and larger, respectively, than those under other treatments. 
Table 2. Effects of VPD and soil moisture on the growth of tomato and cumber plants.

\begin{tabular}{cccccc}
\hline \multirow{2}{*}{ Treatments } & \multicolumn{2}{c}{ Plant Height $\mathbf{( c m )}$} & \multicolumn{2}{c}{ Stem Diameter (mm) } \\
\cline { 2 - 6 } & & Tomato & Cucumber & Tomato & Cucumber \\
\hline \multirow{2}{*}{ HVPD } & WW & $81.2 \pm 2.2 \mathrm{a}$ & $128.5 \pm 4.6 \mathrm{bc}$ & $6.4 \pm 0.2 \mathrm{ab}$ & $6.1 \pm 0.1 \mathrm{bcd}$ \\
& WS & $68.5 \pm 1.6 \mathrm{bc}$ & $131.5 \pm 5.2 \mathrm{~b}$ & $5.86 \pm 0.1 \mathrm{bcd}$ & $5.9 \pm 0.1 \mathrm{~cd}$ \\
\hline \multirow{2}{*}{ LVPD } & WW & $79.5 \pm 1.2 \mathrm{a}$ & $146 \pm 6.61 \mathrm{a}$ & $7.2 \pm 0.1 \mathrm{a}$ & $6.5 \pm 0.1 \mathrm{abc}$ \\
& WS & $69 \pm 3.1 \mathrm{~b}$ & $135.7 \pm 3.1 \mathrm{ab}$ & $6.5 \pm 0.2 \mathrm{ab}$ & $6.2 \pm 0.2 \mathrm{bcd}$ \\
\hline
\end{tabular}

Note: Data are presented as means \pm standard error $(n=10)$. Letters represent significant differences between treatments. Different letters indicate significant differences $(p<0.05)$. WW (well-watered, 100\%FC) + HVPD (high vapor pressure deficit); WW (well-watered, 100\%FC) + LVPD (low vapor pressure deficit); WS (water stress, $60 \% \mathrm{FC}$ ) + HVPD (high vapor pressure deficit); WS (water stress, 60\% FC) + LVPD (low vapor pressure deficit).

\subsection{Effects of VPD and Soil Moisture on Plant Biomass}

Changes in moisture content significantly affected both fresh and dry biomass. The fresh and dry weights of tomato plants with $100 \% \mathrm{FC}$ treatment were both higher, which increased by $40.25 \%$ and $36.79 \%$, respectively, compared with $60 \% \mathrm{FC}$. The dry weight of cucumber plants also showed a similar pattern (Figure 6).
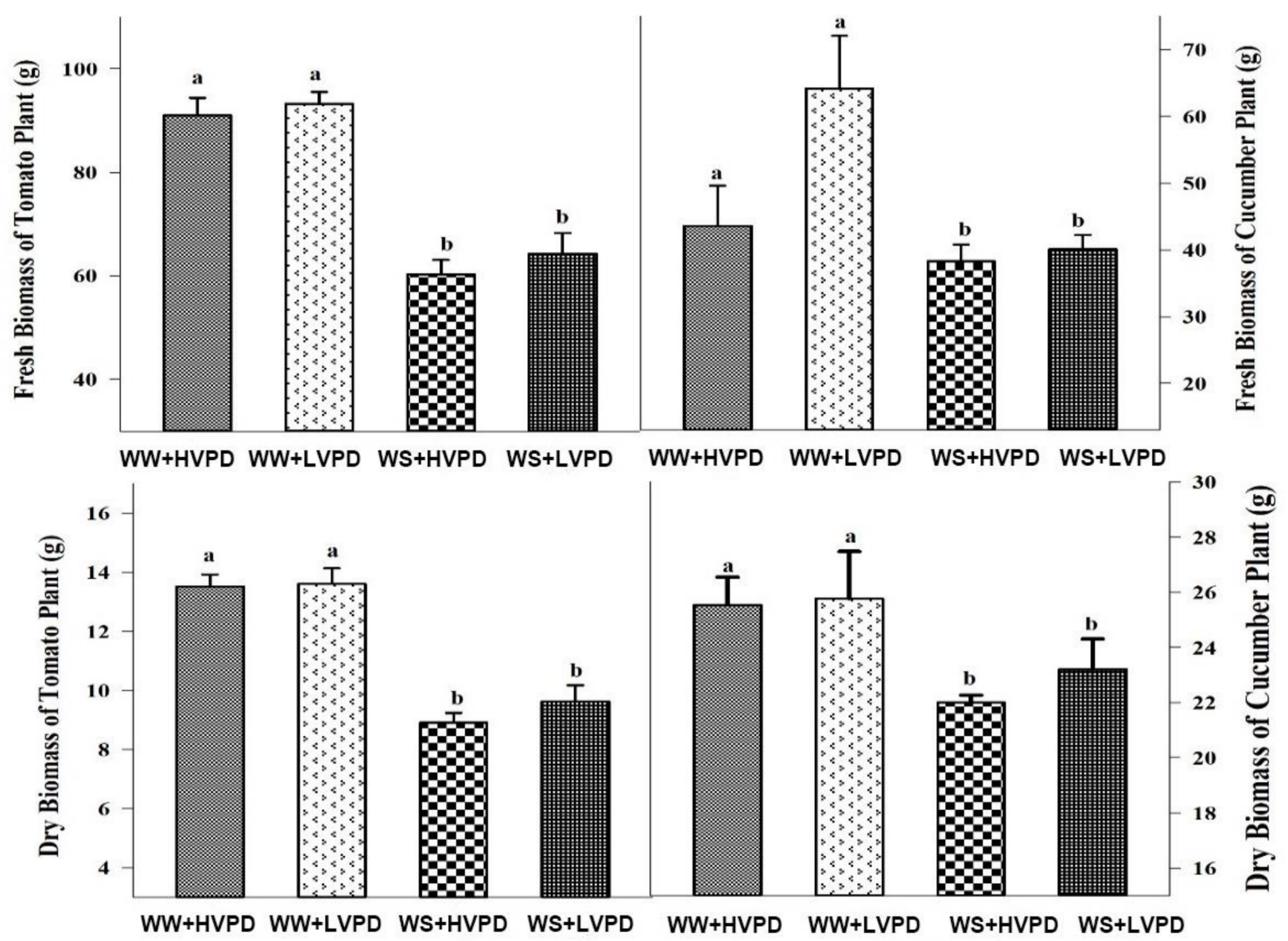

Figure 6. Effects of VPD and soil moisture on the fresh and dry biomasses of tomato and cucumber plants. Data are presented as means \pm standard error $(n=10)$. Letters represent significant differences between treatments. Different letters indicate significant differences $(p<0.05)$. WW (well-watered, $100 \%$ FC) + HVPD (high vapor pressure deficit); WW (well-watered, 100\%FC) + LVPD (low vapor pressure deficit); WS (water stress, 60\%FC) + HVPD (high vapor pressure deficit); WS (water stress, $60 \% \mathrm{FC}$ ) + LVPD (low vapor pressure deficit). 


\subsection{Effects of VPD and Soil Moisture on Leaf Chlorophyll Content}

The chlorophyll content of tomato plants increased gradually in the first 30 days and decreased in the last 20 days. The maximum chlorophyll content occurred after 30 days under HVPD with $100 \% \mathrm{FC}$. In cucumber plants, chlorophyll content under all treatments increased gradually with time. The maximum content was reached after 45 days under LVPD and $100 \%$ FC (Figure 7).

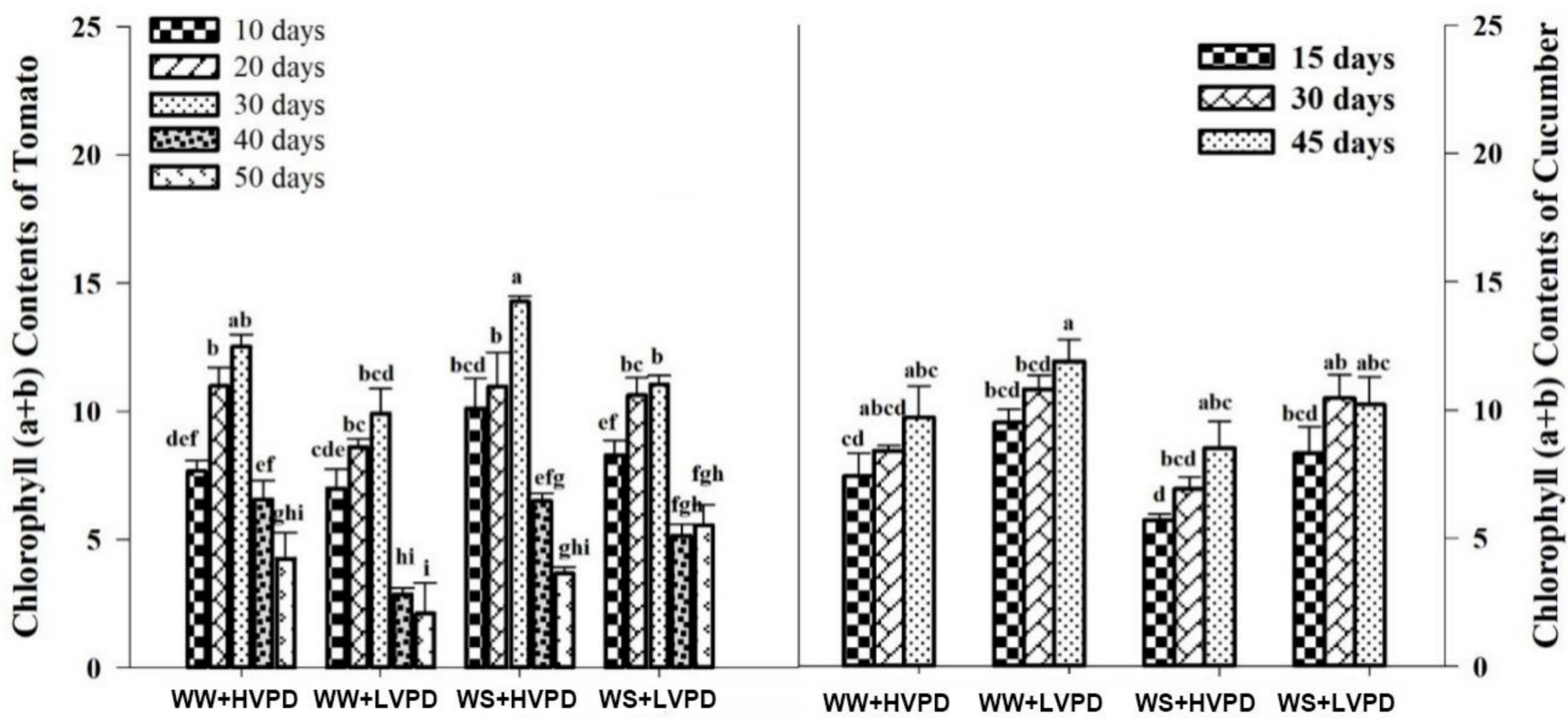

Figure 7. Effects of VPD and soil moisture on the chlorophyll contents of tomato plants. Data are presented as mean \pm standard error $(n=10)$. Letters represent significant differences between treatments. Different letters indicate significant differences $(p<0.05)$. WW (well-watered, 100\%FC) + HVPD (high vapor pressure deficit); WW (well-watered, 100\%FC) + LVPD (low vapor pressure deficit); WS (water stress, 60\%FC) + HVPD (high vapor pressure deficit); WS (water stress, 60\%FC) + LVPD (low vapor pressure deficit).

\subsection{Effects of VPD and Soil Moisture on Plant Antioxidant Enzymes}

SOD activity showed a no-significant difference under HVPD and LVPD with WS. Plants under LVPD and 60\%FC exhibited the lowest SOD activity, whereas those under HVPD with $100 \%$ FC showed the highest. Similarly, POD and CAT activities were altered significantly with $100 \%$ FC under LVPD and HVPD. The highest POD and CAT activities were observed in plants under LVPD with $60 \% \mathrm{FC}$, whereas the lowest were observed in plants under HVPD with $60 \% \mathrm{FC}$. The highest values for APX activity were observed under LVPD with $60 \% \mathrm{FC}$ and the lowest were observed under HVPD with $100 \% \mathrm{FC}$. Furthermore, MDA was highest in plants under HVPD with $60 \% \mathrm{FC}$, followed by that in plants under LVPD with $60 \%$ FC (Figure 8 ). 


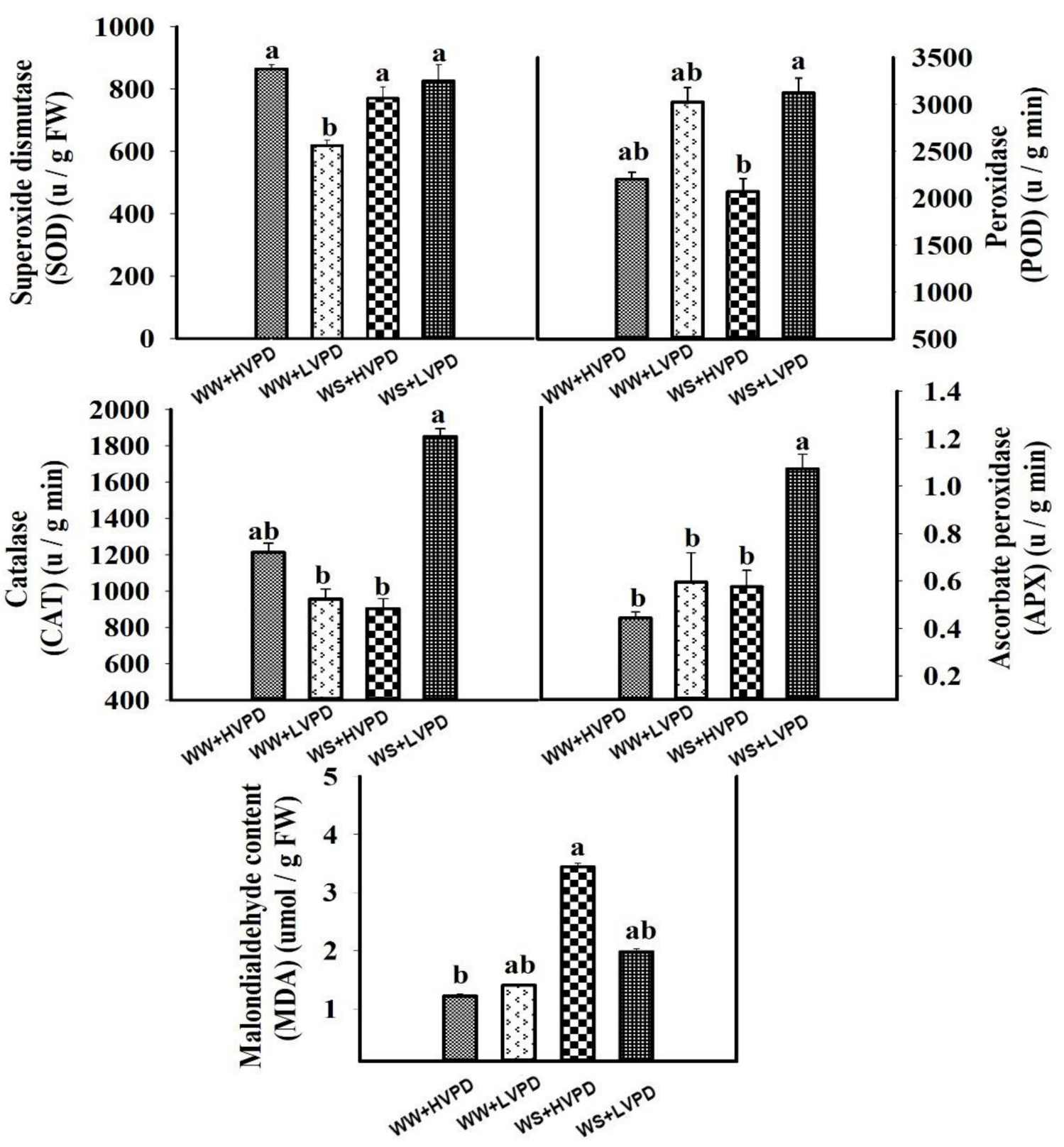

Figure 8. Effects of VPD and soil moisture content on the SOD, POD, CAT, and APX activities and MDA contents in tomato. Data represent means \pm standard error $(n=10)$. Letters represent significant differences between treatments. Different letters indicate significant differences $(p<0.05)$. WW (wellwatered, 100\%FC) + HVPD (high vapor pressure deficit); WW (well-watered, 100\%FC) + LVPD (low vapor pressure deficit); WS (water stress, $60 \% \mathrm{FC}$ ) + HVPD (high vapor pressure deficit); WS (water stress, 60\%FC) + LVPD (low vapor pressure deficit).

\section{Discussion}

VPD has a considerable influence on the photosynthetic capacity of plants in the dry atmosphere of the greenhouse during the day [33]. In the present study, we found that the growth of both species in a controlled environment could be promoted by enhancing photosynthesis. In plants, WS $(60 \% \mathrm{FC})$ directly affected height and growth [34] by arresting water transportation. In plants, stress conditions affect normal growth by altering physiological and biochemical processes [35]. The reduction in water and nutrient availability leads to a reduction in photosynthesis and alterations in source-sink relationships [36]. We found that cucumber plants exhibited relatively increased heights and stem diameters under all the investigated conditions. The same results were observed in tomato plants. 
Specifically, tomato plants grown with 100\%FC under HVPD and LVPD showed greater heights and diameters than those grown with 60\%FC. VPD may play an effective role in increasing the height of different plant species.

Atmospheric water pressure deficit is an important factor that defines the rate of water transport and transpiration efficiency in plant systems [37]. Additionally, it is involved in regulating plant productivity under WS [38]. Our study revealed that the absence of drought and LVPD significantly increased the RWC in tomato and cucumber most likely because the uptake of water and nutrients was at its maximum and, consequently, increased photosynthesis [39].

The EC plays an important role in determining the survival rate of plants under different environmental conditions [21]. The EC is related to the adaptation of plants under stress conditions [40]. In accordance with results in previous studies, the EC of both crops under HVPD was higher than that under LVPD with $100 \%$ FC in this study. In contrast, increased EC was observed in tomato plants with $60 \% \mathrm{FC}$ under LVPD because LVPD cannot mitigate the effect of soil drought [41].

Plant photosynthesis regulates growth and development [37]. It directly affects biomass and yield production in plants [36]. Growth analysis with gas exchange parameters showed that plant productivity was significantly enhanced by improving photosynthesis capacity [42]. The cucumber and tomato plants grown under LVPD with $60 \%$ FC showed higher photosynthetic rates than those grown under other treatments. The elevation in the photosynthesis rate can be ascribed to the regulation of stomatal closure and the limitation of $\mathrm{CO}_{2}$ uptake [38]. Stomatal closure is mainly regulated by guard cells [40]. The direct connections among plant water status, water transport, and turgor pressure influences the physiology of guard cells [43].

Leaf gas exchange parameters are linked to the amount of net photosynthetic carbon assimilation. Gs plays a crucial role in leaf gas exchange [44]. Plants exhibited higher exchange rates under LVPD with $100 \% \mathrm{FC}$ and $60 \% \mathrm{FC}$ than under other treatments. In contrast, tomato plants showed a low exchange rate with $60 \% \mathrm{FC}$. However, LVPD rescued the drought-induced reduction in Gs (Figure 5). The obtained results may be attributed to the effect of water status on stomatal morphology [45]. The reduction in stomatal aperture with $60 \%$ FC was rescued by LVPD. Plants with $60 \%$ FC showed impaired plant growth, whereas those with $100 \%$ FC showed increased dry mass under LVPD. This effect may be attributed to the increase in photosynthetic activity induced by $100 \%$ FC under LVPD. The correlation between biomass and photosynthesis has been attributed to the increase in carbohydrate production induced by high photosynthetic activity [46]. A positive correlation was observed between plant Tr and Gs under the regulation of VPD (Figure S1). The application of VPD technology sufficiently reduced water loss and enhanced the WUE under WS. Therefore, VPD can be recommended to address the water loss problem encountered during regular irrigation in general crop cultivation.

Biomass is generally considered as a good indicator of overall plant growth [47]. VPD regulates plant growth, yield production, and overall biomass [48]. Total biomass is restricted by HVPD [49]. In our experiment, cucumber and tomato plants showed high biomasses with 100\%FC under LVPD, but low biomasses with $60 \%$ FC under HVPD, most likely because the LVPD provided by the fogging system increased photosynthetic rates. Given that photosynthesis provides starch for plant growth, plant growth and photosynthesis are strongly linked [50].

WS has been considered as the major constraint in plant chlorophyll degradation, which ultimately affects plant photosynthetic activity and overall biomass production [51]. In our study, under LVPD with $60 \%$ FC, tomato plants showed high chlorophyll content, whereas cucumbers showed low chlorophyll content. The improved action of chlorophyllase under stress may compensate for chlorophyll content and reduced stomatal conductance and photosynthesis, and change basic relationships [52]. Similar results have also been reported for maize under drought [53]. Therefore, VPD is an important factor for regulating plant chlorophyll content. 
Water deficit triggers the production of ROS, which cause cell disruption and oxidize unsaturated fatty acids, proteins, and DNA [54]. The additional oxidative stress produced by water deficit conditions causes the imbalance of several physiological and biochemical reactions that then stimulates plant antioxidant defense systems [55]. Antioxidant enzymatic systems (SOD, POD, and CAT) are believed to be the first line of defense able to scavenge overproduced ROS and alleviate stress [56]. The increased POD, CAT, and APX activities in our experiment can be attributed to physiological improvements under LVPD + WS treatments and reduced lipid peroxidation rates (MDA). Our results were in accordance with previous findings showing that plant antioxidant defense enzymes scavenge overproduced ROS and mitigate cell membrane damage [57]. MDA is a wax peroxidation product that acts as a dependable oxidative stress indicator in animals and plants [58]. The MDA contents of water-stressed and well-watered plants differed under LVPD and HVPD. These findings indicated that the water deficit treatment did cause a noticeable degree of oxidative stress in the plants due to the activation of effective antioxidant systems [59]. Overall, the activities of these antioxidant enzymes were improved in response to LVPD with $60 \%$ FC.

\section{Conclusions}

Soil moisture and VPD had significant effects on the growth of tomato and cucumber plants. Tomato and cucumber plants responded differently to changes in soil and air water conditions. Maintaining VPD at low levels by using different systems can significantly improve vegetable cultivation under greenhouse conditions in regions of the world with temperate continental climates, by prolonging plant water availability in WS environments. Future research should explore the plant structure of water transmission and find its correlation with physiological parameters.

Supplementary Materials: The following supporting information can be downloaded at: https:/ /www. mdpi.com/article/10.3390/horticulturae8020147/s1, Figure S1: Experiment equipment installation design and greenhouse cultivation; Figure S2: Correlation analysis of all experiment parameters which affected by vapor pressure deficit (VPD) and soil relative water capacity (FC); Table S1: Two-factor analysis of variance (ANOVA) between vapor pressure deficit (VPD) and soil relative water capacity (FC) on cucumber and tomato experiment parameters.

Author Contributions: Conceptualization, X.S. and J.L.; methodology, M.I. and L.M.; software, M.I. and L.M.; resources, X.J.; writing-original draft preparation, M.I.; writing-review and editing, X.S.; supervision, J.L.; project administration, J.L. All authors have read and agreed to the published version of the manuscript.

Funding: This research was funded by the National Key Research and Development Program of China (2019YFD1001903); Regional Innovation Capability Guidance Program of Shaanxi Province Science and Technology Department (2021QFY08-04); Scientific and Technological Innovative Research Team of Shaanxi Province (2021TD-34).

Institutional Review Board Statement: Not applicable.

Informed Consent Statement: Not applicable.

Data Availability Statement: Data is contained within the article.

Acknowledgments: We thank the Horticulture Science Research Center at College of Horticulture, NWAFU for their technical support in this work.

Conflicts of Interest: The authors declare no conflict of interest. 


\section{References}

1. Allen, C.D.; Macalady, A.K.; Chenchouni, H.; Bachelet, D.; McDowell, N.; Vennetier, M.; Kitzberger, T.; Rigling, A.; Breshears, D.D.; Hogg, E.H. A global overview of drought and heat-induced tree mortality reveals emerging climate change risks for forests. For. Ecol. Manag. 2010, 259, 660-684. [CrossRef]

2. $\quad$ Arve, L.E.; Kruse, O.M.; Tanino, K.K.; Olsen, J.E.; Futsaether, C.; Torre, S. Daily changes in VPD during leaf development in high air humidity increase the stomatal responsiveness to darkness and dry air. J. Plant Physiol. 2017, 211, 63-69. [CrossRef] [PubMed]

3. Lu, N.; Nukaya, T.; Kamimura, T.; Zhang, D.; Kurimoto, I.; Takagaki, M.; Maruo, T.; Kozai, T.; Yamori, W. Control of vapor pressure deficit (VPD) in greenhouse enhanced tomato growth and productivity during the winter season. Sci. Hortic. 2015, 197, 17-23. [CrossRef]

4. Du, Q.; Xing, G.; Jiao, X.; Song, X.; Li, J. Stomatal responses to long-term high vapor pressure deficits mediated most limitation of photosynthesis in tomato. Acta Physiol. Plant. 2018, 40, 149. [CrossRef]

5. Zhou, S.; Yu, B.; Zhang, Y.; Huang, Y.; Wang, G. Water use efficiency and evapotranspiration partitioning for three typical ecosystems in the Heihe River Basin, northwestern China. Agric. For. Meteorol. 2018, 253, 261-273. [CrossRef]

6. Du, Q.; Liu, T.; Jiao, X.; Song, X.; Zhang, J.; Li, J. Leaf anatomical adaptations have central roles in photosynthetic acclimation to humidity. J. Exp. Bot. 2019, 70, 4949-4961. [CrossRef]

7. Duan, Q.X.; Kleiber, A.; Jansen, K.; Junker, L.V.; Kammerer, B.; Han, G.; Zimmer, I.; Rennenberg, H.; Schnitzler, J.P.; Ensminger, I. Effects of elevated growth temperature and enhanced atmospheric vapour pressure deficit on needle and root terpenoid contents of two Douglas fir provenances. Environ. Exp. Bot. 2019, 166, 103819. [CrossRef]

8. Oliveira, R.S.; Eller, C.B.; Barros, F.d.V.; Hirota, M.; Brum, M.; Bittencourt, P. Linking plant hydraulics and the fast-slow continuum to understand resilience to drought in tropical ecosystems. New Phytol. 2021, 230, 904-923. [CrossRef]

9. Amitrano, C.; Arena, C.; Rouphael, Y.; De Pascale, S.; De Micco, V. Vapour pressure deficit: The hidden driver behind plant morphofunctional traits in controlled environments. Ann. Appl. Biol. 2019, 175, 313-325. [CrossRef]

10. Du, Q.; Zhang, D.; Jiao, X.; Song, X.; Li, J. Effects of atmospheric and soil water status on photosynthesis and growth in tomato. Plant Soil Environ. 2018, 64, 13-19. [CrossRef]

11. Song, X.M.; Bai, P.; Ding, J.P.; Li, J.M. Effect of vapor pressure deficit on growth and water status in muskmelon and cucumber. Plant Sci. 2021, 303, 110755. [CrossRef]

12. Cal, A.J.; Sanciangco, M.; Rebolledo, M.C.; Luquet, D.; Torres, R.O.; McNally, K.L.; Henry, A. Leaf morphology, rather than plant water status, underlies genetic variation of rice leaf rolling under drought. Plant Cell Environ. 2019, 42, 1532-1544. [CrossRef]

13. Romero, P.; Lafuente, M.T. Relative humidity regimes modif y epicuticular wax metabolism and fruit properties during Navelate orange conservation in an ABA-dependent manner. Food Chem. 2022, 369, 130946. [CrossRef]

14. Veselov, D.S.; Sharipova, G.V.; Veselov, S.Y.; Dodd, I.C.; Ivanov, I.; Kudoyarova, G.R. Rapid changes in root HvPIP2; 2 aquaporins abundance and ABA concentration are required to enhance root hydraulic conductivity and maintain leaf water potential in response to increased evaporative demand. Funct. Plant Biol. 2018, 45, 143-149. [CrossRef]

15. Perez-Jimenez, M.; Carmen Pinero, M.; del Amor, F.M. Heat shock, high $\mathrm{CO}_{2}$ and nitrogen fertilization effects in pepper plants submitted to elevated temperatures. Sci. Hortic. 2019, 244, 322-329. [CrossRef]

16. Cardoso, A.A.; Randall, J.M.; Jordan, G.J.; McAdam, S.A.M. Extended differentiation of veins and stomata is essential for the expansion of large leaves in Rheum rhabarbarum. Am. J. Bot. 2018, 105, 1967-1974. [CrossRef]

17. Lin, C.; Gentine, P.; Huang, Y.; Guan, K.; Kimm, H.; Zhou, S. Diel ecosystem conductance response to vapor pressure deficit is suboptimal and independent of soil moisture. Agric. For. Meteorol. 2018, 250, 24-34. [CrossRef]

18. Wu, X.; Wu, C.; Bian, Z.; Ye, Z.; Meng, L.; Xia, L.; Bao, E.; Cao, K. Abscisic acid and reactive oxygen species were involved in slightly acidic electrolyzed water-promoted seed germination in watermelon. Sci. Hortic. 2022, 291, 110581. [CrossRef]

19. Rasheed, F.; Dreyer, E.; Richard, B.; Brignolas, F.; Brendel, O.; Le Thiec, D. Vapour pressure deficit during growth has little impact on genotypic differences of transpiration efficiency at leaf and whole-plant level: An example from Populus nigra L. Plant Cell Environ. 2015, 38, 670-684. [CrossRef]

20. Geron, C.; Rasmussen, R.; Arnts, R.R.; Guenther, A. A review and synthesis of monoterpene speciation from forests in the United States. Atmos. Environ. 2000, 34, 1761-1781. [CrossRef]

21. Dong, X.; Tang, H.; Zhang, Q.; Zhang, C.; Wang, Z. Transcriptomic analyses provide new insights into jujube fruit quality affected by water deficit stress. Sci. Hortic. 2022, 291, 110558. [CrossRef]

22. Magdziak, Z.; Golinski, P.; Gasecka, M.; Budka, A.; Mleczek, M. Differentiation in low molecular weight organic acids exudation into rhizosphere and their creation in Ulmus laevis Pall organs treated by As-Pot experiment. Chem. Ecol. 2019, 35, 36-53. [CrossRef]

23. Rodriguez-Calzada, T.; Qian, M.; Strid, A.; Neugart, S.; Schreiner, M.; Torres-Pacheco, I.; Guevara-Gonzalez, R.G. Effect of UV-B radiation on morphology, phenolic compound production, gene expression, and subsequent drought stress responses in chili pepper (Capsicum annuum L.). Plant Physiol. Biochem. 2019, 134, 94-102. [CrossRef]

24. Lamoureux, S.C.; Poot, P.; Veneklaas, E.J. Shallow soils negatively affect water relations and photosynthesis in two semi-arid Eucalyptus species. Environ. Exp. Bot. 2018, 155, 239-250. [CrossRef]

25. Zhang, D.; Zhang, Z.; Li, J.; Chang, Y.; Du, Q.; Pan, T. Regulation of vapor pressure deficit by greenhouse micro-fog systems improved growth and productivity of tomato via enhancing photosynthesis during summer season. PLoS ONE 2015, 10, e0133919. [CrossRef] 
26. Zhang, D.; Jiao, X.; Du, Q.; Song, X.; Li, J. Reducing the excessive evaporative demand improved photosynthesis capacity at low costs of irrigation via regulating water driving force and moderating plant water stress of two tomato cultivars. Agric. Water Manag. 2018, 199, 22-33. [CrossRef]

27. Liu, H.; Zhu, Y.; Liu, X.; Jiang, Y.; Deng, S.; Ai, X.; Deng, Z. Effect of artificially accelerated aging on the vigor of Metasequoia glyptostroboides seeds. J. For. Res. 2020, 31, 78-88. [CrossRef]

28. Liu, G.; Du, Q.; Jiao, X.; Li, J. Irrigation at the level of evapotranspiration aids growth recovery and photosynthesis rate in tomato grown under chilling stress. Acta Physiol. Plant. 2017, 40, 2. [CrossRef]

29. Giannopolitis, C.N.; Ries, S.K. Superoxide dismutase I. Occurrence in higher plants. Plant Physiol. 1972, 59, 309-314. [CrossRef]

30. Booker, R.F.; Burkey, K.; Morgan, P.; Fiscus, E.; Jones, A. Minimal influence of G-protein null mutations on ozone-induced changes in gene expression, foliar injury, gas exchange and peroxidase activity in Arabidopsis thaliana L. Plant Cell Environ. 2012, 35, 668-681. [CrossRef]

31. Liu, T.; Hu, X.; Zhang, J.; Zhang, J.; Du, Q.; Li, J. $\mathrm{H}_{2} \mathrm{O}_{2}$ mediates ALA-induced glutathione and ascorbate accumulation in the perception and resistance to oxidative stress in Solanum lycopersicum at low temperatures. BMC Plant Biol. 2018, 18, 34. [CrossRef]

32. Gaion, L.A.; Carvalho, R. Stomatal response to drought is modulated by gibberellin in tomato. Acta Physiol. Plant. 2021, 43, 129. [CrossRef]

33. Grossiord, C.; Buckley, T.N.; Cernusak, L.A.; Novick, K.A.; Poulter, B.; Siegwolf, R.T.W.; Sperry, J.S.; McDowell, N.G. Plant responses to rising vapor pressure deficit. New Phytol. 2020, 226, 1550-1566. [CrossRef]

34. Olukomaiya, O.O.; Adiamo, O.Q.; Fernando, W.C.; Mereddy, R.; Li, X.; Sultanbawa, Y. Effect of solid-state fermentation on proximate composition, anti-nutritional factor, microbiological and functional properties of lupin flour. Food Chem. 2020, 315, 126238. [CrossRef]

35. Wang, L.; Hou, D.; Cao, Y.; Ok, Y.S.; Tack, F.M.G.; Rinklebe, J.; O'Connor, D. Remediation of mercury contaminated soil, water, and air: A review of emerging materials and innovative technologies. Environ. Int. 2020, 134, 105281. [CrossRef]

36. Stirbet, A.; Lazar, D.; Guo, Y.; Govindjee, G. Photosynthesis: Basics, history and modelling. Ann. Bot. 2020, 126, 511-537. [CrossRef]

37. Walker, A.P.; De Kauwe, M.G.; Bastos, A.; Belmecheri, S.; Georgiou, K.; Keeling, R.F.; McMahon, S.M.; Medlyn, B.E.; Moore, D.J.P.; Norby, R.J. Integrating the evidence for a terrestrial carbon sink caused by increasing atmospheric $\mathrm{CO}_{2}$. New Phytol. 2021, 229, 2413-2445. [CrossRef]

38. Mathias, J.M.; Thomas, R.B. Global tree intrinsic water use efficiency is enhanced by increased atmospheric $\mathrm{CO}_{2}$ and modulated by climate and plant functional types. Proc. Natl. Acad. Sci. USA 2021, 118, e2014286118. [CrossRef]

39. Hoshika, Y.; Osada, Y.; de Marco, A.; Penuelas, J.; Paoletti, E. Global diurnal and nocturnal parameters of stomatal conductance in woody plants and major crops. Glob. Ecol. Biogeogr. 2018, 27, 257-275. [CrossRef]

40. Hasan, M.M.; Gong, L.; Nie, Z.-F.; Li, F.-P.; Ahammed, G.J.; Fang, X.-W. ABA-induced stomatal movements in vascular plants during dehydration and rehydration. Environ. Exp. Bot. 2021, 186, 104436. [CrossRef]

41. Silva, L.C.R.; Lambers, H. Soil-plant-atmosphere interactions: Structure, function, and predictive scaling for climate change mitigation. Plant Soil 2021, 461, 5-27. [CrossRef]

42. $\mathrm{Mu}, \mathrm{X} . ;$ Chen, $\mathrm{Y}$. The physiological response of photosynthesis to nitrogen deficiency. Plant Physiol. Biochem. 2021, 158, 76-82. [CrossRef]

43. Xu, B.; Long, Y.; Feng, X.; Zhu, X.; Sai, N.; Chirkova, L.; Betts, A.; Herrmann, J.; Edwards, E.J.; Okamoto, M. GABA signalling modulates stomatal opening to enhance plant water use efficiency and drought resilience. Nat. Commun. 2021, 12, 1952. [CrossRef]

44. Xiong, D.; Douthe, C.; Flexas, J. Differential coordination of stomatal conductance, mesophyll conductance, and leaf hydraulic conductance in response to changing light across species. Plant Cell Environ. 2018, 41, 436-450. [CrossRef]

45. Aliniaeifard, S.; Matamoros, P.M.; van Meeteren, U. Stomatal malfunctioning under low VPD conditions: Induced by alterations in stomatal morphology and leaf anatomy or in the ABA signaling? Physiol. Plant. 2014, 152, 688-699. [CrossRef]

46. Ding, Z.; Ali, E.F.; Elmahdy, A.M.; Ragab, K.E.; Seleiman, M.F.; Kheir, A.M.S. Modeling the combined impacts of deficit irrigation, rising temperature and compost application on wheat yield and water productivity. Agric. Water Manag. 2021, $244,106626$. [CrossRef]

47. Arun, J.; Gopinath, K.P.; Sivaramakrishnan, R.; SundarRajan, P.; Malolan, R.; Pugazhendhi, A. Technical insights into the production of green fuel from $\mathrm{CO}_{2}$ sequestered algal biomass: A conceptual review on green energy. Sci. Total Environ. 2021, 755, 142636. [CrossRef]

48. Massmann, A.; Gentine, P.; Lin, C.J. When does vapor pressure deficit drive or reduce evapotranspiration? J. Adv. Model. Earth Syst. 2016, 11, 3305-3320. [CrossRef]

49. Merilo, E.; Yarmolinsky, D.; Jalakas, P.; Parik, H.; Tulva, I.; Rasulov, B.; Kilk, K.; Kollist, H. Stomatal VPD response: There is more to the story than ABA. Plant Physiol. 2018, 176, 851-864. [CrossRef]

50. Ma, Y.; Xu, D.; Sang, S.; Jin, Y.; Xu, X.; Cui, B. Effect of superheated steam treatment on the structural and digestible properties of wheat flour. Food Hydrocoll. 2021, 112, 106362. [CrossRef]

51. Liu, L.; Li, D.; Ma, Y.; Shen, H.; Zhao, S.; Wang, Y. Combined application of arbuscular mycorrhizal fungi and exogenous melatonin alleviates drought stress and improves plant growth in tobacco seedlings. J. Plant Growth Regul. 2021, 40, 1074-1087. [CrossRef]

52. Wang, X.; Li, Q.; Xie, J.; Huang, M.; Cai, J.; Zhou, Q.; Dai, T.; Jiang, D. Abscisic acid and jasmonic acid are involved in drought priming-induced tolerance to drought in wheat. Crop J. 2021, 9, 120-132. [CrossRef] 
53. Zhang, Y.-Y.; Gao, S.; Minh-Tu, H.; Wang, Z.-W.; Ma, X.; Zhai, Y.; Li, N.; Zhao, L.-X.; Fu, Y.; Ye, F. Protective efficacy of phenoxyacetyl oxazolidine derivatives as safeners against nicosulfuron toxicity in maize. Pest Manag. Sci. 2021, 77, 177-183. [CrossRef] [PubMed]

54. Abd El-Mageed, T.A.; Rady, M.M.; Taha, R.S.; Abd El Azeam, S.; Simpson, C.R.; Semida, W.M. Effects of integrated use of residual sulfur-enhanced biochar with effective microorganisms on soil properties, plant growth and short-term productivity of Capsicum annuum under salt stress. Sci. Hortic. 2020, 261, 108930. [CrossRef]

55. Ainsworth, E.A.; Lemonnier, P.; Wedow, J.M. The influence of rising tropospheric carbon dioxide and ozone on plant productivity. Plant Biol. 2020, 22, 5-11. [CrossRef]

56. Halliwell, B. Reactive species and antioxidants. Redox biology is a fundamental theme of aerobic life. Plant Physiol. 2006, 141, 312-322. [CrossRef]

57. Jalal, A.; de Oliveira Junior, J.C.; Ribeiro, J.S.; Fernandes, G.C.; Mariano, G.G.; Rezende Trindade, V.D.; dos Reis, A.R. Hormesis in plants: Physiological and biochemical responses. Ecotoxicol. Environ. Saf. 2021, 207, 111225. [CrossRef]

58. Gao, Y.-F.; Liu, J.-K.; Yang, F.-M.; Zhang, G.-Y.; Wang, D.; Zhang, L.; Ou, Y.-B.; Yao, Y.-A. The WRKY transcription factor WRKY8 promotes resistance to pathogen infection and mediates drought and salt stress tolerance in Solanum lycopersicum. Physiol. Plant. 2020, 168, 98-117. [CrossRef]

59. Saleem, M.H.; Kamran, M.; Zhou, Y.; Parveen, A.; Rehman, M.; Ahmar, S.; Malik, Z.; Mustafa, A.; Anjum, R.M.A.; Wang, B. Appraising growth, oxidative stress and copper phytoextraction potential of flax (Linum usitatissimum L.) grown in soil differentially spiked with copper. J. Environ. Manag. 2020, 257, 109994. [CrossRef] 